УДК 656.073

\title{
АНАЛІЗ СТАНУ ТЕХНОЛОГІЇ ОХОРОНИ ВАНТАЖІВ НА ЗАЛІЗНИЦЯХ УКРАЇНИ
}

Канд. техн. наук Я.В. Запара

\section{АНАЛИЗ СОСТОЯНИЯ ТЕХНОЛОГИИ ОХРАНЫ ГРУЗОВ НА ЖЕЛЕЗНЫХ ДОРОГАХ УКРАИНЫ}

Канд. техн. наук Я.В. Запара

\section{ANALYSIS OF TECHNOLOGY OF GOODS ON RAILWAYS OF UKRAINE}

\section{Candidate of techn. sciences Y. Zapara}

Проведення аналізу стану технології охорони вантажів залізнииями України дозволило виявити ї̈ недосконалість в окремих аспектах, які можуть стати підгрунтям для розроблення комплексної низки заходів, щчо будуть спрямовані на якісну організащію роботи охорони вантажів.

Ключові слова: незбереження перевезень, комериійна робота, комериійна несправність, контроль за станом вантажу, розкрадання, охорона вантажу.

Проведение анализа состояния технологии охраны грузов железными дорогами Украины позволило выявить её несовершенство в отдельных аспектах, которые могут стать основой для разработки комплексного ряда мероприятий, какие будут направлень на качественную организачию работы охраны грузов.

Ключевые слова: несохранность перевозок, коммерческая работа, коммерческая неисправность, контроль за состоянием груза, хищения, охрана груза.

The research status and providing quality technology of goods against theft during transportation by rail Ukraine, the example of the Southern Railway. In particular, the report analyzes the size of losses by type of goods, causes unsaved traffic and responsibilities among departments railway, which will offer relevant suggestions for improvement of safety of goods.

We found that a significant impact on the safety of cargo has the technical condition of rolling stock and personal characteristics of goods, the highest percentage size distribution losses accounted for the transportation of light oil, steel and other non-food goods, the highest percentage of responsibility for neshoronnist goods falls to the lot of departmental militarized security and left on the balance rail. All this points to the need to improve the technology of transportation on railways of Ukraine.

Keywords: nonconservation of transportation, commerce, commercial failure, monitoring of cargo theft, cargo security.

Вступ. Залізничний транспорт галузь, що виконує перевезення великих обсягів вантажів широкої номенклатури. В цьому процесі схоронності та безпеці виконання перевезень постійно приділяється увага. Оскільки, в забезпеченні першого показника (схоронності) зацікавлені клієнти, які обрали та довірили залізничному транспорту своє майно, а залізнична галузь поважає цю довіру, то другий показник забезпечення безпеки перевезення - це напрямок, якого повинні дотримуватися всі учасники перевізного процесу, оскільки його забезпечення гарантує цілісність та схоронність не тільки вантажу та 
транспортних засобів, а і здоров'я тих, хто бере участь в організації їх обслуговування та транспортування.

Постановка проблеми у загальному вигляді та іï зв'язок із важливими науковими та практичними завданнями. Відповідно до Державної програми реформування залізничного транспорту на 2008-2015 роки та наказу Міністерства внутрішніх справ України і Міністерства транспорту та зв’язку України за № $404 / 624$, для забезпечення зниження обсягів збитків, пов'язаних 3 охороною вантажів (розкрадання), поліпшення технології охорони вантажів при перевезенні залізницями України, на підставі аналізу стану охорони вантажів 3 урахуванням особливостей вантажу та умов перевезення, $\epsilon$ необхідність розроблення пропозицій щодо забезпечення охорони вантажів та недопущення їх розкрадань.

Аналіз останніх досліджень і публікацій. Питаннями забезпечення схоронності вантажів при перевезенні залізничним транспортом у різні часи займалися відомі вчені, такі як В.М. Запара, Д.В. Ломотько, А.М. Котенко, А.О. Поляков, А.О. Смєхов та багато інших. Серед останніх робіт, присвячених цьому питанню, слід відзначити [1]. У працях недостатньо уваги приділено взаємодії залізниці та суміжних органів, зокрема воєнізованої охорони і працівників міліції.

Визначення мети та задачі дослідження. Метою роботи $\epsilon$ проведення досліджень щодо стану та забезпечення якісної технології охорони вантажів проти розкрадань при перевезенні залізницями України. Задачі дослідження полягають у проведенні аналізу розмірів збитків за видами вантажів, причинами виникнення незбережених перевезень та відповідальністю серед підрозділів залізниці, що дозволить запропонувати відповідні пропозиції для покращення показників схоронності вантажів.

Основна частина дослідження. При виконанні умов договору перевезення основні зобов'язання, що покладаються на залізницю, - це вчасно та в повному обсязі доставити вантаж до пункту призначення. Для деякої номенклатури вантажів наявність відсотка втрат $\epsilon$ показником постійним, який однак можна намагатися зменшувати, враховуючи характер основних причин, що його обумовлюють. Так, при перевезенні сипучих вантажів причини втрат можна узагальнити так: невідповідність рухомого складу, який надається для перевезення вантажу, особливо при тривалій експлуатації вагона, що має вплив на його технічний стан; недостатнє використання надійних та економічних заходів, які запобігають втратам вантажу в умовах експлуатації залізниць.

При перевезенні сипучих вантажів на відкритому рухомому складі мають місце три види втрат: витікання вантажу в конструктивні зазори; видування дрібних фракцій повітряними потоками; осипання частин вантажу 3 верхньої частини штабеля, що завантажений вище рівня бортів напіввагона (платформи).

Незважаючи на різноманіття факторів, що впливають на втрату сипучих вантажів при транспортуванні, головними $€$ : швидкість руху поїзда, вологість, конструкція вагона, його технічний стан, дальність перевезення, спосіб завантаження - ступінь ущільнення, висота над рівнем бортів та ін. [3].

Основні причини незбереження перевезень штучних вантажів у критих вагонах: механічні пошкодження (проколи, проломи, потертості) в результаті зсуву, розвалу i зміщення вантажу; приймання вантажу в неякісній і нестандартній тарі; неправильне укладання вантажу у вагони та інші причини.

До того ж, причини виникнення втрат вантажу в умовах експлуатації залізниць можуть бути розділені і за характером виникнення на технічні, технологічні та комерційні. 
Побудовано гістограму відповідності розподілів збитків за видами причин виникнення незбережених перевезень на Південній залізниці за період 2009-2012 pр. (рис. 1), а також гістограму відповідності розподілу збитків за видами вантажів (рис. 2).

Згідно 3 нормативною документацією та службовими інструкціями порядок дій працівників, що беруть участь в роботі 3 вантажами на різних стадіях їх транспортування, спрямований на забезпечення обробки, обліку та забезпечення схоронності вантажів.

Загальне керівництво та організація роботи щодо забезпечення збереженості вантажів, їх охорони на станціях здійснюється начальником станції. Контроль за станом вантажів, які прибувають на станцію в поїздах i відправляються зі станції, виконується працівниками станції на пунктах комерційного огляду (КО).

У випадках, коли завантаження виконується силами та засобами відправника вантажу, як на території станції, так і на під'їзних коліях, прийомоздавач може виконати лише перевірку цілісності кузова вагона, надійності закриття люків і дверей, прибирання “старих" закруток, ЗПП, розміток; а також звірити відповідність номера вагона, кількість ЗПП та відбитків на корпусі ЗПП з даними, що внесені в перевізні документи [4].

Забезпечення збереженості вантажів у вагонах, відчеплених від поїздів на вантажних станціях для усунення несправностей, які загрожують збереженості вантажів, або для попередження їх виникнення, покладаються на працівників технічного обслуговування вагонів на коліях технічного обслуговування (ПТО) та працівників комерційного обслуговування на пунктах комерційного огляду (ПКО) або на коліях усунення комерційних несправностей.

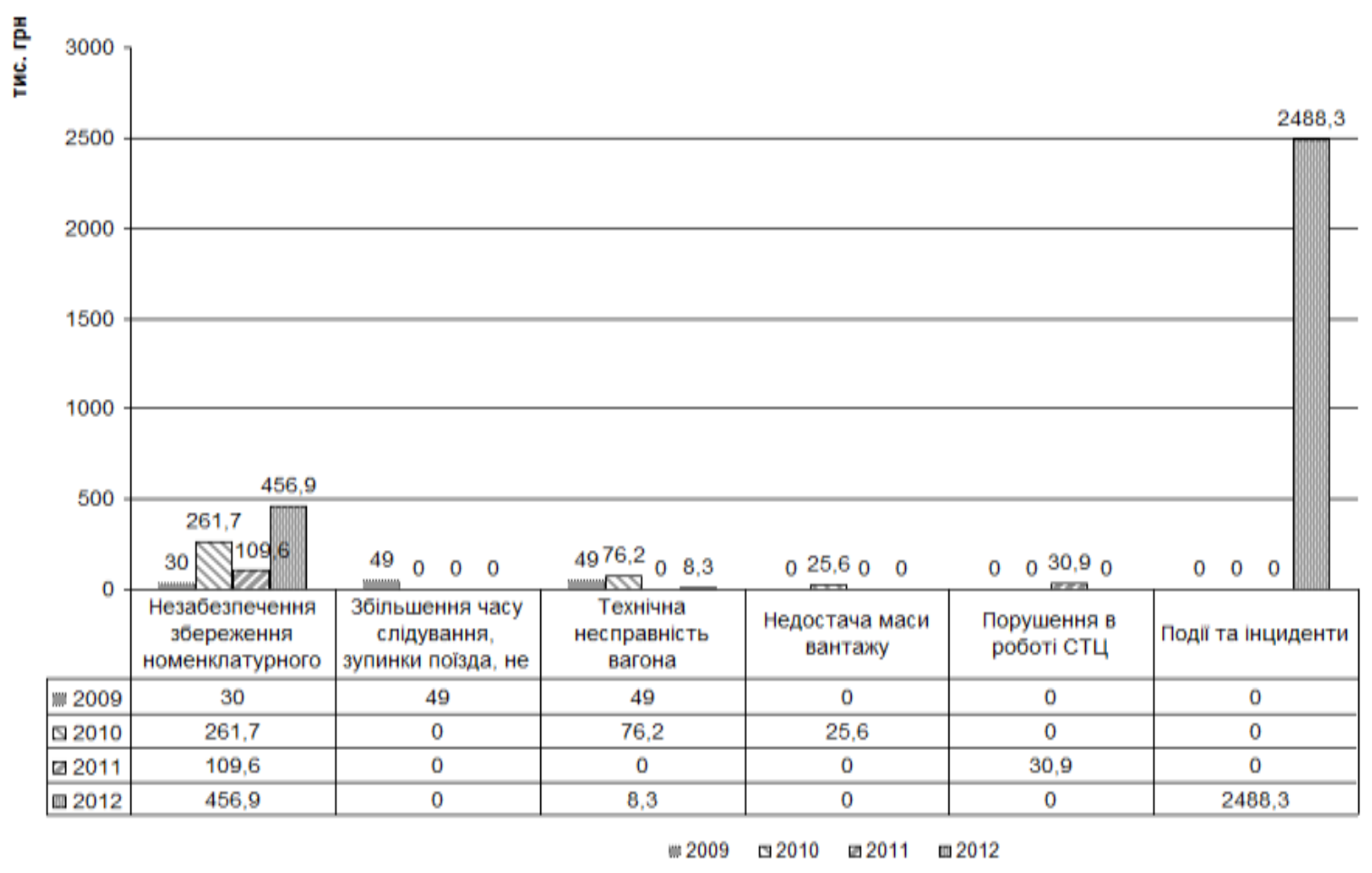

Рис. 1. Гістограма відповідності розподілу розмірів збитків за видами причин виникнення незбережених перевезень 


\section{Експлуатація залізниць}

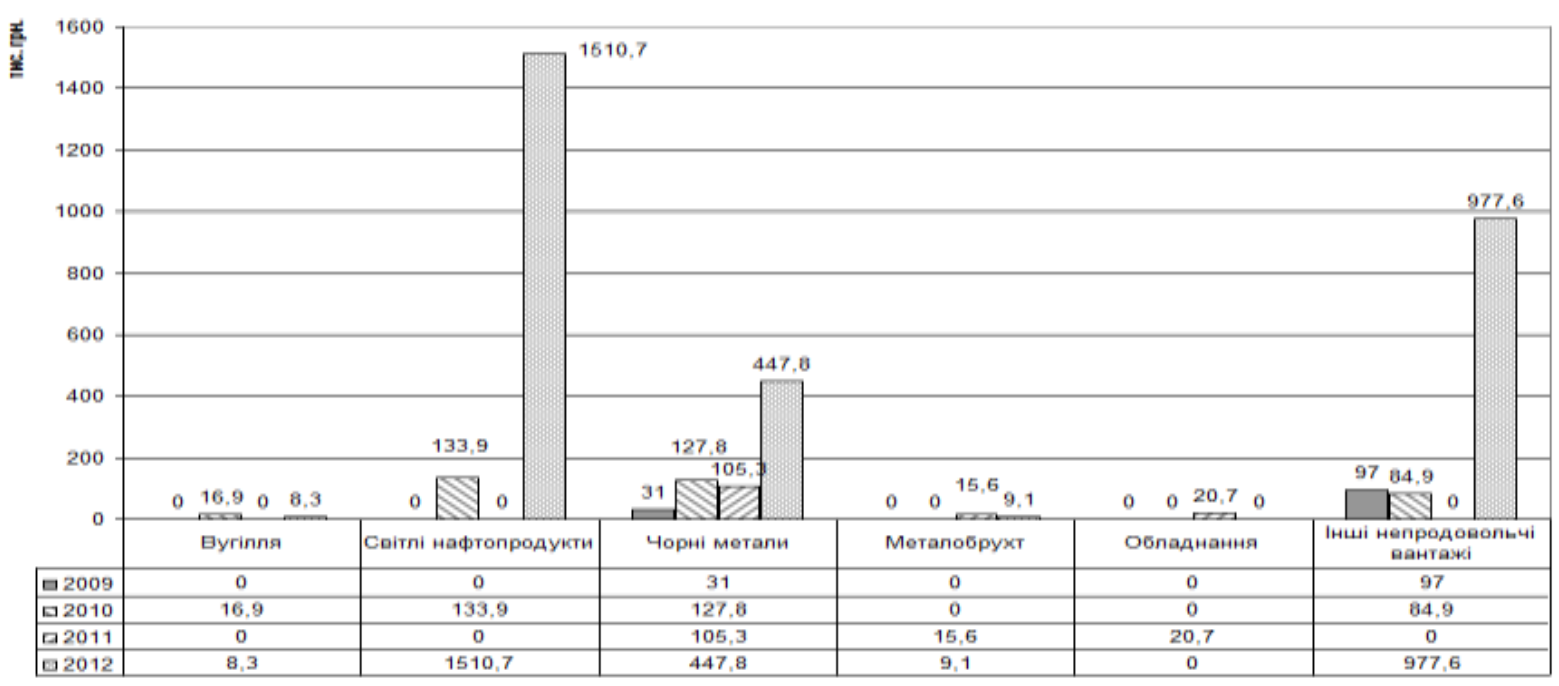

ロ2009ロ2010ロ2011 ロ2012

Рис. 2. Гістограма відповідності розподілу розмірів збитків за видами вантажів при незбережених перевезеннях

Технологія роботи ПКО має забезпечувати якісний КО усіх поїздів і вагонів за час, зазначений у технологічних процесах роботи ПКО. Розроблення Технологічних процесів виконується відповідно до Типового технологічного процесу роботи ПКО [5].

Контроль за станом вантажів виконується працівниками станції згідно 3
Правилами комерційного огляду поїздів та вагонів [6].

Відповідно до даних за оперативними обставинами та проведеною роботою на Південній залізниці за період 2009 - 2012 pp. побудовано гістограму відповідності розподілів збитків по відповідних підрозділах залізниці (рис. 3).

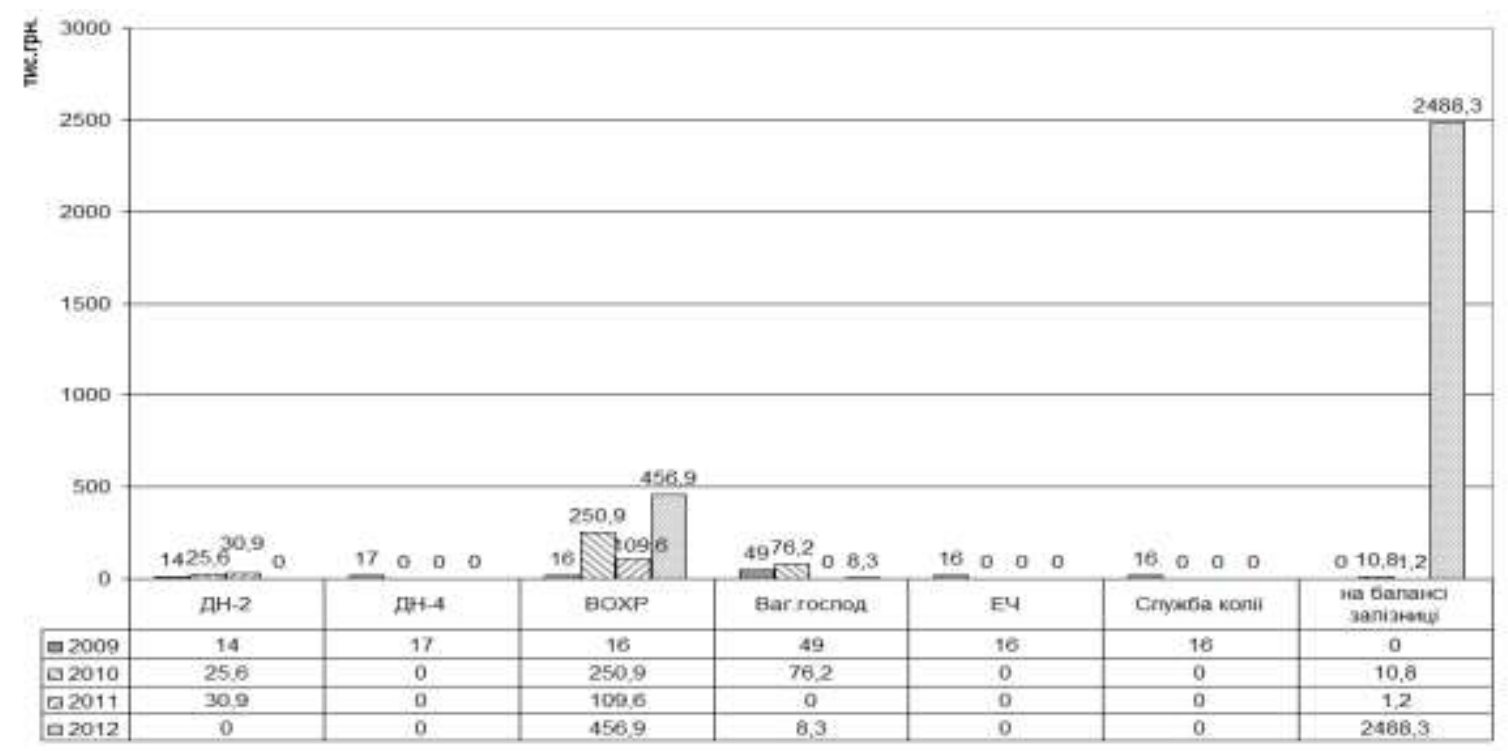

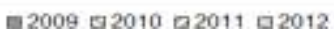

Рис. 3. Гістограма відповідності розподілу розмірів збитків по відповідним підрозділах залізниці 
Усунення комерційних несправностей здійснюється, як правило, без відчеплення вагонів від поїзда. Однак відчеплення вагонів допускається, якщо усунення несправностей за час стоянки поїзда, передбаченої технологічним процесом роботи станції, неможливе або за необхідності перевірки стану та кількості вантажу (за 2012 рік по УЗ було відчеплено 6417 ваг., в т.ч. по Південній залізниці 120 ваг.).

При виявленні вагонів із ознаками розкрадання вантажу негайно інформується воєнізована охорона залізниці й органи внутрішніх справ на транспорті. Огляд вагонів, що підлягають супроводженню воєнізованою охороною залізниць, здійснюється разом з працівниками станції [5].

Для здійснення охорони вантажів в парках станцій та на шляху прямування робота виконується стрілецькими командами. Вантажі, що перевозяться згідно 3 Правилами перевезень вантажів залізничним транспортом у супроводі провідників відправників (одержувачів), охороняються цими провідниками без участі працівників станції і працівників відомчої воєнізованої охорони.

Висновки 3 дослідження i перспективи, подальший розвиток у даному напрямку. В результаті аналізу основних причин незбережених перевезень, що можуть виникнути з деякими групами вантажів, професійними обов'язками працівників, причетних до забезпечення схоронності перевезень, а також відповідно до даних на Південній залізниці за період 2009-2012 рр. зроблено такі висновки:

1. Значний вплив на схоронність вантажів має технічний стан рухомого складу та особисті характеристики вантажів;

2. Найбільший відсоток розподілу розмірів збитків на прикладі Південної залізниці за видами вантажів при незбережених перевезеннях за період 2009-2012 pp. припадає на перевезення світлих нафтопродуктів, чорних металів та інших непродовольчих вантажів.

3. Найбільший відсоток відповідальності за несхоронність вантажів припадає на частку відомчої воєнізованої охорони та залишається на балансі залізниці.

Отже, пропозиції щодо забезпечення якісної технології охорони вантажів проти розкрадань при перевезенні повинні розглядатися комплексно 3 урахуванням удосконалення нормативно-правового забезпечення та організаційнотехнологічного аспекту діяльності причетних структур. Такі ж дослідження повинні бути виконані i для інших залізниць України.

\section{Список використаних джерел}

1. Ломотько, Д.В. Підвищення рівня схоронності вантажів, що перевозять по залізницях України [Текст] / Д.В. Ломотько, М.М. Кузнецов, О.М. Пилипейко // Наука в транспортном измерении. - К.: ДНДЦ УЗ, 2006. - С. 67.

2. Смехов, А.А. Грузоведение, сохранность и крепление грузов [Текст] / А.А. Смехов, А.Д. Малов, А.М. Островский [и др.]; под. ред. А.А. Смехова. - М. : Транспорт, 1987. - 239 с.

3. Посібник прийомоздавальника вантажу та багажу (ЦМ-0016) [Текст]: нормативнотехнічне видання; наказ Укрзалізниці № 388-Ц від 31.07.2007 р. - К. : Укрзалізниця, 2008. $224 \mathrm{c}$.

4. Типовий технологічний процес роботи пункту комерційного огляду поїздів (ПКО) [Текст]: нормативно-технічне видання; наказ Укрзалізниці № 178-Ц від 28.03.2007 р. - К. : ТОВ “ВД “Мануфактура", 2007. - 28 с. 


\section{Експлуатація залізниць}

5. Правила комерційного огляду поїздів та вагонів [Текст]: нормативно-технічне видання; наказ Укрзалізниці № 152-Ц від 26.04.2006 р. - К.: ТОВ “Швидкий рух”, 2006. $32 \mathrm{c}$.

$$
\text { Рецензент д-р техн. наук, професор О.М. Огар }
$$

Запара Ярослав Вікторович, кандидат техн. наук, старший викладач кафедри управління вантажною та комерційною роботою Української державної академії залізничного транспорту. Тел.: (057) 730-10-85.

E-mail: y.zapara@gmail.com

Zapara Yaroslav V. Ph.D., Senior Lecturer of freight and commercial work Ukraine State Academy of Railway Transport. Tel.: (057) 730-10-85. E-mail: y.zapara @ gmail.com 